\title{
Short communication: Production, distribution and conservation analysis of Cherax crayfish endemic to Papua and West Papua Provinces, Indonesia
}

\author{
FERLIANA WIDYASARI ${ }^{1}$, MOHAMMAD SAYUTI ${ }^{2, \boldsymbol{\nu}}$, RANDI BOKHY SYULIANA SALAMPESSY ${ }^{3}$ \\ ${ }^{1}$ Coastal and Marine Resource Management Center of Sorong. Jl. KPR PDAM Km 10, Klawuyuk, Sorong City 98416, West Papua, Indonesia \\ ${ }^{2}$ Politeknik Kelautan dan Perikanan Sorong, Jl. Kapitan Pattimura, Suprau, Tanjungkasuari, Maladummes, Sorong City 98411, West Papua, Indonesia. \\ Tel./fax.: +62-951-333741, ”email: mohsayut@gmail.com \\ ${ }^{3}$ Program of Fish Processing Technology, Politeknik Ahli Usaha Perikanan. Jl. Pasar Minggu, South Jakarta 12520, Jakarta, Indonesia
}

Manuscript received: 22 March 2021. Revision accepted: 22 May 2021.

\begin{abstract}
Widyasari F, Sayuti M, Salampessy RBS. 2021. Short communication: Production, distribution and conservation analysis of Cherax crayfish endemic to Papua and West Papua Provinces, Indonesia. Biodiversitas 22: 3271-3276. Freshwater crayfish is a species from the Parastacidae family that is indigenous to Papua and West Papua Indonesia. This study analyzes the amount of production, economic value, distribution, and conservation of freshwater crayfish endemic to Papua and West Papua. The production data were obtained from Stasiun Karantina Ikan or Fish Quarantine Inspection Agency in Papua and West Papua, Indonesia. Data regarding the price of Cherax crayfish were determined based on interviews with freshwater crayfish sellers. Furthermore, the distribution of freshwater crayfish was explained based on a literature review, while the data of its conservation were retrieved from the IUCN Red List of Threatened Species. Cherax crayfish caught from wild populations in West Papua is known higher than in Papua. Increased sales revenue could support the economy of the local community. There have been 25 species of freshwater crayfish identified, nine of which were from West Papua and 16 from Papua. Three species were under Endangered (EN), Least Concern (LC), Vulnerable (VU) status, respectively. Four species were under Data Deficient (DD) status, while the rest were unidentified. Overfishing of Cherax crayfish causes decline Cherax crayfish stock in the wild, future researchers are expected to conduct more specific studies that include relevant stakeholders regarding the conservation of Cherax crayfish that are endemic to Papua and West Papua.
\end{abstract}

Keywords: Cherax, conservation, crayfish, IUCN red list, Papua, production

\section{INTRODUCTION}

Freshwater crayfish found in New Guinea island has been studied by a number of researchers including (Holthuis 1949; Holthuis 1956; Holthuis 1958; Holthuis 1986; Holthuis 1996) as well as (Lukhaup and Pekny 2006; Lukhaup and Herbert 2008; Lukhaup and Pekny 2008; Lukhaup 2015; Lukhaup et al. 2015; Patoka et al. 2015a; Patoka et al. 2015b; Lukhaup et al. 2017; Patoka et al 2017; Lukhaup et al. 2018 and Sedik et al. 2018). Species from genus Cherax crayfish generally traded as ornamental fish (Chucholl 2013; Papavlasopoulou et al. 2014; Patoka et al. 2014). Cherax crayfish from Papua are generally caught from nature then collected and sent to Java (Jakarta and Surabaya), and then exported by Indonesian wholesalers to Asia, the US, and Europe (Lukhaup and Herbert 2008; Patoka et al. 2015b), also been bred in aquariums or ponds as ornamental fish because Cherax crayfish not prone to stress and diseases (Iskandar 2003).

Seen from the technical aspects of breeding and market potential, Cherax crayfish can be widely bred to provide economic benefits for the community while its conservation can be maintained. Regarding its natural environment, Indonesia has enormous potential for Cherax crayfish breeding. The climate and seasonal cycles allow Cherax crayfish to be bred throughout the year. Red claws
(C. quadricarinatus) can lay eggs 4-5 times a year, while in Queensland, Australia, red claws can only lay eggs twice a year (Wiyanto and Hartono 2003). Cherax crayfish has an important ecological in freshwater ecosystem which one is as a component food chain, larvae Cherax crayfish serves as food for larger aquatic animals, while the adult of this Cherax crayfish has a cannibal when they lack food and when they live in a dense population (Abinawanto et al. 2018) although Cherax crayfish are generally active foraging at night (nocturnal) and also includes all-eating types (omnivores) (Wiyanto and Hartono 2003). This cannibal nature starts to appear since it is still young (Wiyanto and Hartono 2003), and Cherax crayfish will prey on other crayfish that are sick or moulting because they are in a weak condition and they secrete a lubricating hormone (pheromone) with a strong smell, making it easier for other Cherax crayfish to prey on them (Iskandar 2003). Young Cherax crayfish are usually only take a few seconds to molt, while Cherax crayfish are more mature takes about 3-4 minutes for molting (Wiyanto and Hartono 2003). Cherax crayfish will be more frequent molting for good growth (Lukito and Prayugo 2007).

The demands for Cherax crayfish for consumption come from Japan, Malaysia, Hong Kong, China, Taiwan, Korea and Singapore. In addition, people in the United States, Canada, France, the Netherlands, Germany, 
Belgium, New Zealand and Australia also find Cherax crayfish a favorite cuisine believed healthier than seafood (Kurniasih 2008). Besides, the fat, cholesterol and salt contents are lower, so it is safe for consumption for everyone (Wiyanto and Hartono 2003). Some people believe that Cherax crayfish meat can boost vitality and sexual arousal in women. Rich zinc content can stimulate libido and increase sperm activities in men (Iskandar 2003).

With these benefits, the Cherax crayfish are high in demand globally at a high price. The selling price of Cherax crayfish in Jakarta market size young $5 \mathrm{~cm}$ up/ 2 inches up/ 2 months old up 0.17 USD with amount 100 heads up; 0.2 USD with amount under 100 heads; 0.34 USD with amount under 30 heads; size broodstocks (big) 1 set contains 5 females, 3 males 23.5 USD for size $10 \mathrm{~cm} / 4$ inches/4 months old; 33.5 USD for size $11.5 \mathrm{~cm} / 4.5$ inches $/ 5$ months old and 50 USD for size $12.5 \mathrm{~cm} / 5$ inches/6 months old (BFC Farm 2021). The price of 2-inch ornamental crayfish around 2 USD (Setiawan 2006). Wiyanto and Hartono (2003) stated that the price of consumption Cherax crayfish in big cities in Indonesia ranged from 14-20 USD per kg, with 9-12 Cherax crayfish per $\mathrm{kg}$.

Studies on Cherax crayfish endemic to Papua and West Papua have been widely carried out, but studies were still limited on its species and biological aspects. There is no factual data of the excessive exploitation of Cherax crayfish from nature originating from Papua and West Papua available, making its conservation status unclear. This study determined the production, economic value, distribution, and study the conservation of Cherax crayfish endemic to Papua and West Papua.

\section{MATERIALS AND METHOD}

Data on the amount of production and economic value of Cherax crayfish were collected from Fish Quarantine Class II of Sorong for the West Papua region, Fish Quarantine Class II of Jayapura and Fish Quarantine of Merauke for the Papua region from 2016-2020. All Fish Quarantine is under Ministry of Marine Affairs and Fisheries of Republic Indonesia. The data on the selling price of Cherax crayfish obtained from interviews with sellers who arranged sales permits to the local Quarantine were used as the reference in calculating the estimated value of the product.
Data on the distribution of Cherax crayfish in Papua and West Papua were obtained through a literature review. The data were mapped with Arcgis program version 10.4 to provide information related to the existence of Cherax crayfish in Papua and West Papua.

The conservation status determination refers to the IUCN Red List, which is a categorization applied by the IUCN (International Union for the Conservation of Nature and Natural Resources) in classifying the conservation statuses of various species (IUCN 2021).

Conservation categories based on the IUCN Redlist Version 2021-1 include Extinct (EX; Extinct) is a conservation status given to a species proven that the last individual of the species is already dead; Extinct in the Wild (EW) is a conservation status labelled to species only found in captivity or outside their natural habitat; Critically Endangered (CR) is a conservation status for species at risk of extinction in the near future; Endangered (EN) is a conservation status for species that are at high risk of extinction in the wild in the future; Vulnerable (VU) is a conservation status for species at risk of extinction in the wild in the future; Near Threatened (NT) is a conservation status for species that may be in a threatened or near endangered state, even though they are not under threatened status; Least Concern (LC) is the category for species that have been evaluated but do not match any category; Data Deficient (DD) refers to a taxon defined as "information deficient" when the information is insufficient to estimate extinction risk based on population distribution and status; Not Evaluated (NE) refers to a taxon declared "not evaluated" when it is not evaluated for the above criteria.

Interviews using questionnaire with the community of Sawiyat Village, Sawiyat Sub-district, South Sorong District, where Cherax crayfish was often caught, resulted in data related to catches and responses related to the conservation plan.

\section{RESULTS AND DISCUSSIONS}

\section{Production and product value of Cherax crayfish in Papua and West Papua Province}

Based on the Cherax crayfish trade traffic data from Sorong Fish Quarantine Agency, Jayapura Fish Quarantine Agency and Merauke Fish Quarantine Agency, Cherax crayfish production and product value in Papua and West Papua are presented in Table 1.

Table 1. Data on the production and product value of Cherax crayfish from Papua and West Papua in 2016-2020

\begin{tabular}{lcccc}
\hline \multirow{2}{*}{ Years } & \multicolumn{2}{c}{ Production of Cherax crayfish (individual) } & \multicolumn{2}{c}{ Product value of Cherax crayfish (USD) } \\
\cline { 2 - 5 } & Papua & West Papua & Papua & West Papua \\
\hline 2016 & 19,466 & 60,250 & 16,976 & 709,709 \\
2017 & 51,318 & 67,175 & 44,753 & 69,607 \\
2018 & 25,350 & 60,910 & 22,107 & 80,542 \\
2019 & 11,801 & 70,626 & 10,291 & 37,462 \\
2020 & 13,504 & 32,850 & 11,776 & 332,782 \\
Total & 121,439 & 291,811 & 105,904 & \\
\hline
\end{tabular}


Table 1 shows data on Cherax crayfish production in Papua and West Papua, which fluctuates from year to year. All Cherax crayfish production data that enter to Fish Quarantine is only of the catch from nature. Cherax crayfish production in West Papua was more significant than in Papua. The lowest Cherax crayfish production in West Papua was found in 2016 with 60,250 heads, while the highest production occurred in 2019 with a total output of 70,626 heads. The lowest Cherax crayfish production in Papua was found in 2019 with 11,801 heads and the highest one in 2017 with 51,318 heads. Data on Cherax crayfish Production in Quarantine are only limited to one genus, namely Cherax crayfish No production data per species were available that the Cherax crayfish production per species in Papua and West Papua Provinces could not be determined.

There is only information about the number of breeders, while information on average size or weight of freshwater crayfish is not yet available from fish quarantine authorities. There was only one breeder of Cherax crayfish in 2016. The number changed increased to 11 in 2017 and 2018, decreased to 8 in 2019 and 6 in 2020. The selling price of Cherax crayfish in West Papua is approximately USD 1.14/individual, and the selling price of Cherax crayfish in Papua was around USD 0.87/individual. The different prices of Cherax crayfish due to different sellers and also different delivery destinations. Potential decline associated with Cherax crayfish abundance can easily be overlooked due to trade which is not scientifically described and the quantity captured is not registered by the relevant authority (Patoka et al. 2015a). Cherax crayfish was advertised only under the trade name without a scientific species name (Patoka et al. 2014).

Data on the number of cultivators, catchers and processors of Cherax crayfish in either Papua or West Papua were unavailable, so it is requiring surveys to collect data related to the purpose of catching of Cherax crayfish in Papua and West Papua. Whereas, Cherax crayfish from Papua and West Papua is only distributed to domestic markets in some cities, including Jakarta, Denpasar, and Surabaya. Cherax crayfish is an essential commodity with a relatively higher price than other Cherax species (Kusrini et al. 2009; Dewi and Nugraha 2015).

\section{The distribution and conservation status of Cherax crayfish in Papua and West Papua}

Data on the distribution, conservation, and data released by the International Union for Conservancy Nature (IUCN 2021) regarding status of Cherax crayfish in Papua and West Papua showed that there were 25 species of Cherax crayfish in the Papua and West Papua regions as presented in Table 2.



Figure 1. Distribution of Cherax crayfish in Papua and West Papua, Indonesia 
Table 2. Distribution and conservation status of Cherax crayfish in Papua and West Papua, Indonesia

\begin{tabular}{|c|c|c|c|}
\hline Species & Authors & Distribution & Conservation status \\
\hline Cherax acherontis & (Patoka et al. 2017) & Jayawijaya District (Papua Province) & Not Evaluated (NE) \\
\hline Cherax albertisi & (Blaha et al. 2016; Sugianti and Satria 2017) & Merauke (Papua Province) & Not Evaluated (NE) \\
\hline Cherax alyciae & (Lukhaup et al. 2018) & $\begin{array}{l}\text { Unnamed creek, Boven Digoel District } \\
\text { (Papua Province) }\end{array}$ & Not Evaluated (NE) \\
\hline Cherax boesemani & $\begin{array}{l}\text { (Lukhaup and Pekny, 2008; Blaha } \\
\text { et al. 2016) }\end{array}$ & $\begin{array}{l}\text { Amajaru Lakes, Kais River } \\
\text { Drainage (West Papua } \\
\text { Province) }\end{array}$ & Data deficient (DD) \\
\hline Cherax boschmai & $\begin{array}{l}\text { (Holthuis 1949; Blaha et al. 2016; Crandall } \\
\text { and De Grave 2017) }\end{array}$ & Paniai Lake (Papua Province) & Not Evaluated (NE) \\
\hline Cherax buitendijkae & (Holthuis 1949; Crandall and De Grave 2017) & Paniai Lake (Papua Province) & Not Evaluated (NE) \\
\hline Cherax communis & $\begin{array}{l}\text { (Yogi et al. 2007; Blaha et al. 2016; Crandall } \\
\text { and De Grave 2017) }\end{array}$ & $\begin{array}{l}\text { Paniai Lake, Nabire District (Papua } \\
\text { Province) }\end{array}$ & Not Evaluated (NE) \\
\hline Cherax destructor & (Lekatompessy and da Costa 2019) & $\begin{array}{l}\text { Tigi Lake, Deiyai District (Papua } \\
\text { Province) }\end{array}$ & Vulnerable $(V U)$ \\
\hline Cherax gherardii & $\begin{array}{l}\text { (Patoka et al. 2015a; Blaha et al. 2016; Sedik } \\
\text { et al. 2018) }\end{array}$ & Maybrat (West Papua Province) & Not Evaluated (NE) \\
\hline Cherax holthuisi & (Lukhaup and Pekny 2006; Blaha et al. 2016) & Aitinjo Lake (West Papua Province) & Data deficient (DD) \\
\hline Cherax longipes & $\begin{array}{l}\text { (Holthuis 1949; Blaha et al. 2016; } \\
\text { Lekatompessy and da Costa, 2019) }\end{array}$ & $\begin{array}{l}\text { Tigi Lake, Deiyai District, (Papua } \\
\text { Province) }\end{array}$ & Not Evaluated (NE) \\
\hline Cherax lorentzi & $\begin{array}{l}\text { (Holthuis 1949; Holthuis 1956; Blaha et al. } \\
\text { 2016; Crandall and De Grave 2017) }\end{array}$ & $\begin{array}{l}\text { Painai Lake (Wissel Lake) Papua } \\
\text { Province }\end{array}$ & Data deficient (DD) \\
\hline Cherax minor & (Holthuis 1996; Blaha et al. 2016) & $\begin{array}{l}\text { Eragayam (ex. Wurigelebur) Jaya } \\
\text { Wijaya District (Papua Province) }\end{array}$ & Not Evaluated (NE) \\
\hline Cherax misolicus & $\begin{array}{l}\text { (Holthuis 1949; Blaha et al. 2016; Lukhaup et } \\
\text { al. 2017) }\end{array}$ & $\begin{array}{l}\text { Misool Island, Raja Ampat, (West } \\
\text { Papua Province) }\end{array}$ & Not Evaluated (NE) \\
\hline Cherax monticola & $\begin{array}{l}\text { (Holthuis 1956; Blaha et al. 2016; Gan et al. } \\
\text { 2016) }\end{array}$ & $\begin{array}{l}\text { Habbema Lake and Balim River Camp } \\
\text { on Balim River, East of Habbema } \\
\text { Lake, Baliem River, Wamena (Papua } \\
\text { Province) }\end{array}$ & Data def \\
\hline Cherax mosessalossa & (Lukhaup et al. 2018) & $\begin{array}{l}\text { Klademak Creek, Sorong City (West } \\
\text { Papua Province) }\end{array}$ & Not Evaluated (NE) \\
\hline Cherax murido & $\begin{array}{l}\text { (Holthuis 1949; Blaha et al. 2016; } \\
\text { Lekatompessy and da Costa, 2019) }\end{array}$ & $\begin{array}{l}\text { Tigi Lake, Deiyai District, (Papua } \\
\text { Province) }\end{array}$ & Not Evaluated (NE) \\
\hline Cherax pallidus & (Holthuis 1949; Blaha et al. 2016) & $\begin{array}{l}\text { Wissel Lakes (Paniai, Tage and Tigi) } \\
\text { (Papua Province) }\end{array}$ & Endangered $(E N)$ \\
\hline Cherax paniaicus & $\begin{array}{l}\text { (Holthuis 1949; Fransen at al. 1997; Blaha et } \\
\text { al. 2016) }\end{array}$ & $\begin{array}{l}\text { Lake Paniai, Tage dan Tigi (Papua } \\
\text { Province) }\end{array}$ & Not Evaluated (NE) \\
\hline Cherax pulcher & (Lukhaup, 2015; Blaha et al. 2016) & $\begin{array}{l}\text { Hoa Creek (Teminabuan), } \\
\text { Sorong Selatan (West Papua } \\
\text { Province) }\end{array}$ & Not Evaluated (NE) \\
\hline Cherax quadricarinatus & $\begin{array}{l}\text { (Blaha et al. 2016; (Lekatompessy and da } \\
\text { Costa 2019) }\end{array}$ & $\begin{array}{l}\text { Tigi Lake, Deiyai District (Papua } \\
\text { Province) }\end{array}$ & Least Concern $(L C)$ \\
\hline Cherax snowden & (Lukhaup et al. 2015; Lukhaup et al. 2018) & $\begin{array}{l}\text { Oinsok (Ainsok River Drainage) and } \\
\text { Sawiat Sub-district, West Papua } \\
\text { Province }\end{array}$ & Not Evaluated (NE) \\
\hline Cherax solus & (Lukhaup and Herbert 2008; Blaha et al. 2016) & Tigi Lake (Papua Province) & Not Evaluated (NE) \\
\hline Cherax subterigneus & (Patoka et al. 2015b; Blaha et al. 2016) & Aitinjo Lake (West Papua Province) & Not Evaluated (NE) \\
\hline Cherax warsamsonicus & (Lukhaup et al. 2017) & $\begin{array}{l}\text { Warsamson River, Sorong (West } \\
\text { Papua Province) }\end{array}$ & Not Evaluated (NE) \\
\hline
\end{tabular}

Table 2 and Figure 1 shows the distribution of sixteen (16) species Cherax in Papua and nine (9) species in West Papua. Cherax crayfish was distributed in Nabire, Boven Digoel, Deiyai, Wamena, Merauke, Jayawijaya, Painai District of Papua. Meanwhile, in West Papua Province, Cherax crayfish was distributed in Maybrat, Amajaru, South Sorong, Raja Ampat, Aitinjo, Sorong and Sorong City District. The Papua regions dominate the distribution of Cherax crayfish but the number of Cherax crayfish production is highest in the West Papua regions. The request for freshwater crayfish for Jakarta market reaches 2-3 tons per month, while at the national level it is estimated that the request for freshwater crayfish is between 6-8 tons per month with restaurants as the main absorber (Setiawan 2006). One of the aquarium trading commodities in Surabaya is Cherax quadricarinatus (Indrawati et al. 2016).

Table 2 shows 25 species of Cherax crayfish endemic to Papua and West Papua with different conservation status. There is one species with Endangered (EN) status, 
namely Cherax pallidus. One species, namely Cherax quadricarinatus, is under the Least Concern (LC). Four Cherax species are included in Data Deficient (DD) status, including Cherax boesemani, Cherax monticola, and Cherax holthuisi. The other 18 species are not evaluated (NE) due to lack of information.

Cherax crayfish has been used by local communities for consumption and as an ornamental crayfish commodity (Tanjung 2013). The community in Kampung Sawiyat, Sawiyat Sub-district, South Sorong District started catching Cherax crayfish in 2015 . In that year, Cherax crayfish was still easy to catch, and they could catch 20-30 in one night, and they sold them at the price of USD 0.2/individual. Buyers or collectors of Cherax crayfish were mostly entrepreneurs from Sorong City. In 2020, anglers found it challenging to catch Cherax crayfish due to habitat damage and inappropriate fishing methods, and mining activities of humans. Cherax crayfish preys on one another, and it also eats scavengers and detritus in the waters. Excessive exploitation of Cherax crayfish in nature will have an impact on the food chain. The food chain will be disrupted if one of its components is endangered (Rahmi et al. 2016). The population of Cherax crayfish is being threatened in nature (Sari et al. 2011).

The literature review carried out in this study showed that it is necessary to maintain the population of Cherax crayfish in its natural habitat. Efforts to manage and protect Cherax crayfish need to be taken by considering the aspects of Cherax crayfish conservation. In contrast, the community's economic aspect Cherax crayfish for living should be concerned as well.

In conclusion, there are 25 species of Cherax crayfish endemic to Papua and West Papua Provinces found in Nabire, Boven Digoel, Deiyai, Wamena, Merauke, Jayawijaya, Painai, Maybrat, Amajaru, South Sorong, Raja Ampat, Aitinjo, Sorong and Sorong District. Only data on the use of Cherax crayfish at the Genus level are available. West Papua Province dominated Cherax crayfish production from 2016-2020. IUCN Red List website page showed one species of Cherax is under the Endangered (EN) status. One Cherax species is also categorized as Least Concern (LC), one is under Vulnerable (VU) status, and four species are under Data Deficient (DD) status. Currently, the community has started to catch Cherax crayfish from its natural habitat.

\section{REFERENCES}

Abinawanto, Hamidah H, Bowolaksono A, Eprilurahman R. 2018. Short communication: Biometric of freshwater crayfish (Cherax spp.) from Papua and West Papua, Indonesia. Biodiversitas 19 (2): 489-495. DOI: $10.13057 /$ biodiv/d190216.

BFC Farm. 2021. Pelatihan Budidaya dan Jual Beli Lobster Air Tawar. https://lobsterairtawar001.wixsite.com/lobsterairtawar. [Indonesian]

Blaha M, Patoka J, Kozak P, Kouba A. 2016. Unrecognized diversity in New Guinean crayfish species (Decapoda, Parastacidae): The evidence from molecular data. Integr Zool 11 (6): 457-468. DOI: 10.1111/1749-4877.12211.

Chucholl C. 2013. Invaders for sale: Trade and determinants of introduction of ornamental freshwater crayfish. Biol Invasions 15 (1): 125-141. DOI: 10.1007/s10530-012-0273-2.
Crandall KA, de Grave S. 2017. An updated classification of the freshwater crayfishes (Decapoda: Astacidea) of the world, with a complete species list. J Crustacean Biol 37 (5): 615-653. DOI: 10.1093/jcbiol/rux070.

Dewi, Nugraha RA. 2015. Kajian ekonomi usaha budidaya pembesaran lobster air tawar red claw Hasil tangkapan bubu di Rawa Pening. Akuatik 9 (1): 1-6. [Indonesian]

Fransen CHJM, Holthuis LB, Adema JPHM. 1997. Type-catalogue of the decapod Crustacea in the collections of the Nationaal Natuurhistorisch Museum, with appendices on pre-1900 collectors and material. Zoologische Verhandelingen 311: 1-344

Gan HM, Tan MH, Eprilurahman R, Austin CM. 2016. The complete mitogenome of Cherax monticola (Crustacea: Decapoda: Parastacidae), a large highland crayfish from New Guinea. Mitochondrial DNA 27 (1): 337-338. DOI: 10.3109/19401736.2014.892105.

Holthuis L. 1958. Freshwater crayfish in Netherlands New Guinea Mountains. South Pac Comm Q Bull 8 (2): 36-39.

Holthuis L. 1986. A new genus and species of subterranean shrimp from Western Australia (Crustacea: Decapoda: Atyidae). Zool Med 60 (7): 103-111.

Holthuis LB. 1949. The caridean crustacea of the Canary Islands. Zool Med 30 (31): 227-255.

Holthuis LB. 1956. Native fisheries of freshwater Crustacea in Netherlands New Guinea. in Contributions to New Guinea Carcinology. I. Nova Guinea (n. ser.) 7 (2):123-137.

Holthuis LB. 1996. The mountains of Irian Jaya (W. New Guinea), Indonesia (Crustacea: Decapoda: Parastacidae). Zool Med 70 (24): 361-366.

Indrawati P, Tanziyah LL, Widiawati E, Mardliyah U. 2016. Monitoring perdagangan invertebrata laut sebagai spesimen akuarium di Surabaya. Sains dan Matematika 4 (2): 33-37. [Indonesian]

Iskandar. 2003. Budidaya Cherax. Penebar Swadaya, Jakarta. [Indonesian] IUCN. 2021. The IUCN Red List of Threatened Species. Version 2020-3. https://www.iucnredlist.org/search?query=Cherax $\&$ searchType=speci es.

Kurniasih T. 2008. Lobster air tawar (parastacidae: Cherax), aspek biologi, habitat, penyebaran, dan potensi pengembangannya. Media Akuakultur 3 (1): $\quad 31-35$. DOI: $\quad$ 10.15578/ma.3.1.2008.31-35 [Indonesian]

Kusrini E, Hadie W, Sumantadinata K, Sudradjat A. 2009. Studi morfometrik udang jerbung (Fenneropenaeus merguiensis de Man) dari beberapa populasi. Jurnal Riset Akuakultur 4 (1): 15-21. DOI: 10.15578/jra.4.1.2009.15-21 [Indonesian]

Lekatompessy HS, da Costa GW. 2019. Inventarisasi jenis-jenis lobster air tawar (Cherax sp.) di Danau Tigi, Kampung Widimei, Kabupaten Deiyai. Tabura Jurnal Perikanan dan Kelautan 1 (1): 1-9. [Indonesian]

Lukhaup C. 2015. Cherax (Astaconephrops) pulcher, a new species of freshwater crayfish (Crustacea, Decapoda, Parastacidae) from the Kepala Burung (Vogelkop) Peninsula, Irian Jaya (West Papua), Indonesia. ZooKeys 10 (502): 1-10. DOI: 10.3897/zookeys.502.9800.

Lukhaup C, Eprilurahman R, von Rintelen T. 2018. Two new species of crayfish of the genus Cherax from Indonesian New Guinea (Crustacea, decapoda, parastacidae). ZooKeys 2018 (769): 89-116. DOI: $10.3897 /$ zookeys.769.26095.

Lukhaup C, Eprilurahman R, Von Rintelen T. 2017. Cherax warsamsonicus, a new species of crayfish from the Kepala Burung (Vogelkop) Peninsula in West Papua, Indonesia (Crustacea, Decapoda, Parastacidae). ZooKeys 2017 (660): 151-167. DOI: 10.3897/zookeys.660.11847.

Lukhaup C, Herbert B. 2008. A new species of freshwater crayfish (Crustacea: Decapoda: Parastacidae) from the Fly River Drainage, Western Province, Papua New Guinea. Mem Qld Mus 52 (2): 213219.

Lukhaup C, Panteleit J, Schrimpf A. 2015. Cherax snowden, a new species of crayfish (Crustacea, Decapoda, Parastacidae) from the Kepala Burung (Vogelkop) Peninsula in Irian Jaya (West Papua), Indonesia. ZooKeys 2015 (518): 1-14. DOI: 10.3897/zookeys.518.6127.

Lukhaup C, Pekny R. 2006. Cherax (Cherax) holthuisi, a new species of crayfish (Crustacea: Decapoda: Parastacidae) from the centre of the Vogelkop Peninsula in Irian Jaya (West New Guinea), Indonesia. Zool Med 80 (1): 331-340.

Lukhaup C, Pekny R. 2008. Cherax (Astaconephrops) boesemani, A new species of crayfish (Crustacea: Decapoda: Parastacidae) from the 
centre of the Vogelkop Peninsula in Irian Jaya (West New Guinea), Indonesia. Zool Med (Leiden) 82 (24-41): 331-340.

Lukito A, Prayugo S. 2007. Panduan Lengkap Lobster Air Tawar. Penebar Swadaya, Jakarta. [Indonesian]

Papavlasopoulou I, Perdikaris C, Vardakas L, Paschos I. 2014. Enemy at the gates: Introduction potential of non-indigenous freshwater crayfish in Greece via the aquarium trade. Cent Eur J Biol 9 (1): 1118. DOI: $10.2478 / \mathrm{s} 11535-013-0120-6$.

Patoka J, Bláha M, Kouba A. 2015a. Cherax (Astaconephrops) gherardii, a new crayfish (Decapoda: Parastacidae) from West Papua, Indonesia. Zootaxa 3964 (5): 526-536. DOI: 10.11646/zootaxa.3964.5.2.

Patoka J, Bláha M, Kouba A. 2015b. Cherax (Cherax) subterigneus, a new crayfish (decapoda: Parastacidae) from West Papua, Indonesia. J Crustacean Biol 35 (6): 830-838. DOI: 10.1163/1937240X-00002377.

Patoka J, Bláha M, Kouba A. 2017. Cherax acherontis (Decapoda: Parastacidae), the first cave crayfish from the Southern Hemisphere (Papua Province, Indonesia). Zootaxa 4363 (1): 137-144. DOI: 10.11646/zootaxa.4363.1.7.

Patoka J, Kalous L, Kopecký O. 2014. Risk assessment of the crayfish pet trade based on data from the Czech Republic. Biol Invasions 16 (12): 2489-2494. DOI: 10.1007/s10530-014-0682-5.

Rahmi R, Annawaty A, Fahri F. 2016. Keanekaragaman jenis udang air tawar di Sungai Tinombo Kecamatan Tinombo Kabupaten Parigi Moutong Provinsi Sulawesi Tengah. Nat Sci: J Sci Technol 5 (2):199208. DOI: 10.22487/25411969.2016.v5.i2.6707. [Indonesian]
Sari LK, Iskandar, Astuty S. 2011. Kelangsungan hidup dan pertumbuhan ikan rainbow merah (Glossolepis incisus Weber) dan lobster air tawar (Cherax quadricarinatus) dengan penebaran yang berbeda pada polikultur sistem resirkulasi. Jurnal Perikanan dan Kelautan 3 (1): 4957. [Indonesian]

Sedik Y, Rumahlatu D, Irawan B, Soegianto A. 2018. Morphometric characteristics of crayfish, Cherax gherardiae, from Maybrat, West Papua, Indonesia. Fish Aquat Life 26: 223-230. DOI: 10.2478/aopf2018-0025.

Setiawan C. 2006. Teknik Pembenihan dan Cara Cepat Pembesaran Lobster Air Tawar. PT. Agromedia Pustaka, Jakarta. [Indonesian]

Sugianti Y, Satria H. 2017. Penangkapan ikan di Sungai Maro, Merauke. Bawal Widya Riset Perikanan Tangkap 1 (5): 197-201. DOI: 10.15578/bawal.1.5.2007.197-201. [Indonesian]

Tanjung LR. 2013. Kandungan gizi dan nilai ekonomis pensi, tutut dan Cherax dari Danau Maninjau. Prosiding Seminar Nasional Riset Pangan, Obat-Obatan dan Lingkungan untuk Kesehatan. Lembaga Ilmu Pengetahuan Indonesia, 12 November 2013. [Indonesian]

Wiyanto H, Hartono R. 2003. Cherax, Pembenihan dan Pembesaran. Penebar Swadaya, Jakarta. [Indonesian]

Yogi N, Tasak ER, Haryani GS, Hehanussa PE. 2007. Muna Duma, the Goddess Guard of Lake Paniai, Papua, Indonesia. Proceedings of Taal 2007: The 12th World Lake Conference. Jaipur, Rajasthan, India, 28 October - 2 November 2007. 